in Sir Alfred Ewing's presidential address before the British Association as in the forceful address delivered by Prof. Miles Walker to Section G (Engineering), which referred frankly to the hampering of developments by vested interests and the middleman, as well as to the value of the contribution to the improvement of the lot of mankind made by those who possess the power of devoting their whole energy to the execution of sound, practical, and beneficent projects for the sake of those projects themselves and not primarily from selfish motives or in pursuance of some irrational prejudice. Long after science has shown the way to make things better for the people, unintelligent control and stupid prejudice preserve the old evils and prevent the spread of better ways. If effective action is to be taken, now that in so many fields physical science has instructed man how to control and eliminate waste, the human sciences must show him how to control the waste forces of his own nature.

As an example of the potentialities, Dr. Jacks and Prof. Miles Walker both refer to Lord Baden-Powell's discovery of how the play-hunger of the young human animal, his love of adventure and fun, his sporting instincts, and even his devilries, can be ased by skilful hands for the development of self-control, self-respect, courage, loyalty, discipline, good fellowship, responsibility, and competence. This is a great discovery, to be ranked with any of the achievements of physical science, and is a token of what may be possible when we really address ourselves to the development of the social sciences. The picture Prof. Miles Walker draws of the State as controlled by the engineer, with the elimination of waste at its source, the control of production, improvement of distribution so as to secure the manufacture of things men want and their distribution in the simplest way with the minimum addition to the cost, involves drastic curtailment of competition and perhaps a profound change in our social habits and attitude towards buying and selling. In insisting on technical knowledge and administrative ability as a qualification for public office, he is, however, expounding a doctrine freely voiced in NATURE for many years, and the proposed experiment of a small, relatively self-supporting community is one that should not be without appeal to scientific workers. The time is opportune for courageous and adventurous experiment. The world has yet to receive an objectlesson in the high standard of life which should be possible by good organisation and modern methods, where prejudice and incompetence are no longer allowed to deny to society the benefits of leisure or material possessions with which the application of scientific discoveries would endow them.

\section{Political Economy and Unemployment}

THE confusion which exists in many minds between creative science and mechanical science is apt to obscure the contribution which creative science makes towards the solution of the unemployment problem, a contribution which, under modern conditions, is the more important because so many of the new industries, which fundamental scientific discoveries have created, minister to the increasing leisure needs of mankind. The escape of output from limitations of human effort, resulting from power production, has economic consequences which are already so farreaching that, in the physical sphere, creative science can do little more than mitigate the severity of un. employment, and Mr. H. R. Leech, of 10 Dale Street, Runcorn, has rightly directed our attention to the necessity for original and creative research in that most uncreative of sciences-political economy. It is only as political economy and all the related so-called human sciences are placed on a firm scientific foundation, and as scientific methods are rigorously applied to the analysis of the problems of distribution of leisure and goods with which we are confronted in the age of incredible abundance which science has given us, that we can expect to solve an unemployment problem of the present magnitude. When impartial solutions have been mapped out by scientific methods, there will still remain for scientific workers and others the moral responsibility of seeing that those solutions are applied, and that the profusion with which science has now endowed mankind is no longer permitted to exist side by side with such widespread unemployment, poverty, and distress.

\section{Scientific Research and Industry}

The Committee appointed in March 1931 by the Economic Advisory Council to examine the project for promoting new industrial development in Great Britain by establishing a central national research organisation independent of existing Government and private organisations, has just issued its report. This gives a survey of the existing organisation of industrial research in Great Britain and an analysis of thearguments for a new national research organisation, as well as of proposals for a development fund for the Department of Scientific and Industrial Research, a compulsory levy for support of research associations, and the preparation by Government of scientific digests. The Committee is satisfied that the existing Government organisation for the promotion of industrial research is efficient and sufficiently flexible to enable it to develop along the lines required to meet the changing needs of industry. The formation of a new national research organisation would cut right across the exist. ing organisation of the Department of Scientific and Industrial Research, and, by causing confusion of purpose and distraction of effort, would be likely to injure rather than forward the cause of scientific research in British industry.

\section{Research Development Fund}

THe Committee considers it is highly desirable that the Government should have at its disposal a small fund for research development, and that provision should be made for its continuance when the balance of the fund at the disposal of the Advisory Council for Scientific and Industrial Research is surrendered to the Exchequer at the end of the current year. The Committee refers to evidence received as to the value of the services rendered to industry by the research associations, and trusts that it will be possible for the Government to continue to provide sufficient financial assistance to secure their efficient functioning until industry 